\title{
The Latin American Integration Route and local development in light of the constitutions of Brazil, Paraguay, Argentine and Chile
}

\author{
La Ruta de Integración Latinoamericana y el desarrollo local a la luz de las \\ constituciones de Brasil, Paraguay, Argentina y Chile \\ A Rota de Integração Latino-Americana e o desenvolvimento local à luz das \\ constituições do Brasil, Paraguai, Argentina e Chile
}

\author{
Gabriela Oshiro Reynaldo ${ }^{1}$ \\ Lúcio Flávio Joichi Sunakozawa² \\ Arlinda Cantero Dorsa ${ }^{1}$ \\ Received on 4 July 2021; revised and approved on 9 July 2021; accepted on 28 Sep. 2021 \\ DOI: http://dx.doi.org/10.20435/inter.v22i4.3442
}

\begin{abstract}
Based on the social, legal and economic implications imposed by globalization, as well as the integration between nations, this paper proposes to discuss the concept of development by analyzing the constitutions of Brazil, Paraguay, Argentine, and Chile, considering that a debate between academia and other institutions emerges in the Latin America integration context. This is an urgent and necessary dialogue to guide possible courses for this region. Countries from the most diverse continents already indicate a break in customs tariffs and the rise of new economic agreements, bringing countries of the Latin-American Integration Route (RILA) closer to the countries of today's greatest and most solid economic bloc, the European Union. This sets a precedent for the idea that RILA is becoming a macro-territory of increasing economic, social and legal visibility, which is a reason why thinking about regional development is a priority task, as well as drawing up studies and reflections that lead to a possible harmonization and integration of legal norms. These are tasks of the governments, academia, companies, and civil society. Furthermore, the present work discusses the need for legal grounds involving countries that make up the RILA, in order to provide greater legal security and dignity for the subjects involved in this intense process.
\end{abstract}

Keywords: RILA; south-american constitutions; legal harmonization; local or regional development; latin-american integration.

Resumen: A partir de las implicaciones sociales, legales y económicas que impone la globalización, así como la integración entre naciones, este trabajo propone discutir el concepto de desarrollo a partir del análisis de las constituciones de Brasil, Paraguay, Argentina y Chile, considerando que un debate entre la academia y otras instituciones surge en el contexto de la integración de América Latina. Es un diálogo urgente y necesario para orientar los posibles rumbos de esta región. Los países de los continentes más diversos ya apuntan a una ruptura de los aranceles aduaneros y al surgimiento de nuevos acuerdos económicos, entre ellos el acercamiento de los países miembros de RILA a los países del bloque económico más grande y sólido de la actualidad, la Unión Europea. Esto sienta un precedente para la idea de que RILA se está convirtiendo en un macroterritorio de creciente notoriedad económica, social y jurídica, por lo que pensar en el desarrollo regional es una tarea prioritaria, así como la elaboración de estudios y reflexiones que conduzcan a una posible armonización. e integración de normas legales. Estas son tareas para los gobiernos, el mundo académico, las empresas y la sociedad civil. Además, este trabajo discute la necesidad de un pavimento legal que involucre a los países que integran la RILA, a fin de brindar mayor seguridad jurídica y dignidad a los sujetos involucrados en este intenso proceso.

Palabras clave: RILA; constituciones sudamericanas; armonización jurídica; desarrollo local o regional; integración latino-americana.

Resumo: Com base nas implicações sociais, jurídicas e econômicas impostas pela globalização, bem como a integração entre nações, o presente trabalho se propõe a discutir o conceito de desenvolvimento a partir da análise das Constituições do Brasil, Paraguai, Argentina e Chile, tendo em vista que emerge um debate entre academia e demais instituições no contexto da integração da América Latina. Trata-se de um diálogo urgente e necessário para nortear os possíveis rumos dessa região. Países dos mais diversos continentes já acenam

\footnotetext{
${ }^{1}$ Universidade Católica Dom Bosco, Campo Grande, Mato Grosso do Sul, Brasil.

${ }^{2}$ Universidade Estadual de Mato Grosso do Sul, Dourados, Mato Grosso do Sul, Brasil.
} 
para uma quebra de tarifas alfandegárias e ascensão de novos acordos econômicos, inclusive aproximando os países componentes da RILA dos países do maior e mais sólido bloco econômico da atualidade, a União Europeia. Isso abre um precedente para a ideia que a RILA está se tornando um macro território de crescente notoriedade econômica, social e jurídica, razão pela qual pensar o desenvolvimento regional é tarefa prioritária, bem como traçar estudos e reflexões que levem à uma possível harmonização e integração de normas jurídicas. Essas são tarefas dos governos, academias, empresas e sociedade civil. Ademais, discutese nesse trabalho, a necessidade de uma pavimentação jurídica envolvendo os países que compõem a RILA, a fim de proporcionar maior segurança jurídica e dignidade dos sujeitos envolvidos neste intenso processo.

Palavras-chave: RILA; constituições sul-americanas; harmonização jurídica; desenvolvimento local ou regional; integração latino-americana.

\section{INTRODUCTION}

That globalization has intensified business flow and the movement of goods, people, and information throughout the globe is undeniable. In this context, the expression "integration" becomes mandatory for understanding this contemporary phenomenon, of multidisciplinary and interdisciplinary features, and transnational implications, given that several nations came to think of joining regional blocs or economic networks but ended up involving themselves in a complex range of cultural, social, environmental, legal, public safety, development issues, among other themes.

Notwithstanding the several topics of the above-discussed issues, in order to delimit the theme, this research aims to discuss the concept of development from the constitutions of Brazil, Paraguay, Argentine, and Chile, which are formal legal bases on top of any country's hierarchy of norms, and authorize as conditio sine qua non the implementation of an integrative process between the countries involved, in light of the news and academic, business, and governmental movements in the formation of the so-called Latin-American Integration Route (RILA), or Bioceanic Route.

Thus, in methodological terms, it is relevant to highlight that this is a qualitative, documentary, and bibliographical research of analysis of the referred constitutions and of brief reflections based on theories about the theme at hand. The text here presented is only an essay in the Latin-American Integration Route context, mostly as to the legal and developmental aspect, therefore, of an interdisciplinary nature.

\section{FRONTIERS IN MODERN TIMES}

The frontiers in the 21st century can be conceived as (sub)spaces demanding a careful look and an accurate sociospatial understanding, given the intensity in flows of people, goods, information, and capital. The frontiers represent a space for meeting "the other", the one who possesses a culture and a different reading of the world. The frontiers represent cultural wealth and can be objects of promising economic projects.

In this line of thought, Bertha Becker (2007, p. 41) states that the frontier consists in "[...] a space not fully structured, which, for this very reason, can generate new realities [...]". One understands that the frontier should be thought of as an unfinished space subject to constant transformations.

Hence, we can consider that in the current process of globalization of economy, the meaning of the term frontier spans the discussion about a state's sovereignty and its territorial limits. Currently, the frontier term represents a potential source of promotion of economic 
development and social interaction between nations, has territorial differences in space and time, and according to some authors, under the aspect of political organizations, in a way, the frontiers have economic counterpoints but can also evidence different modi vivendi (OLIVEIRA et al., 2011, p. 81). In this sense, it is relevant to highlight that globalization

[...] is not only the existence of this new system of techniques. It is also the result of actions that assure the emergence of a market said to be global, responsible for the essential in currently effective political processes. The following factors help explain the architecture of current globalization: the unicity of technique, the convergence of moments, the knowability of the planet, and the existence of a single motor of history, represented by globalized surplus value. A global market using this system of advanced techniques results in this perverse globalization. (SANTOS, 2012, p. 23).

In conceptual terms, Raffestin (2005, p. 13) contributes, accurately, to the understanding of frontier and is in this way a guide for the present project: "The frontier is not a line, a frontier is one of the elements of biosocial communication that assumes a regulatory function. It is the expression of a dynamic balance that is not only in the territorial system but in all biosocial systems".

In what concerns the Brazilian frontiers, in territorial terms, Oliveira et al. (2011, p. 82) assert that the country borders ten countries, along this territorial strip are several municipalities with territories full of diversity and tending to agglomerate, as illustrated in Figure 1.

Regarding the Brazilian frontiers, Furtado (2012, p. 246) teaches that "Brazil borders ten countries and is considered that that has greater chances of dialogue with other nations, when compared to the other countries making up the Mercosul group. [...]". Brazil is a country with innumerable potentialities, that is to say, natural resources and human resources, raw material and workforce for transforming it, as well as machinery implementation in the production cycle. In rural areas, for example, Brazil stands out in the use of technology, showing accelerated productivity, and yet, intensifying social inequalities in the struggle for land.

Figure 1 - Brazilian border strip

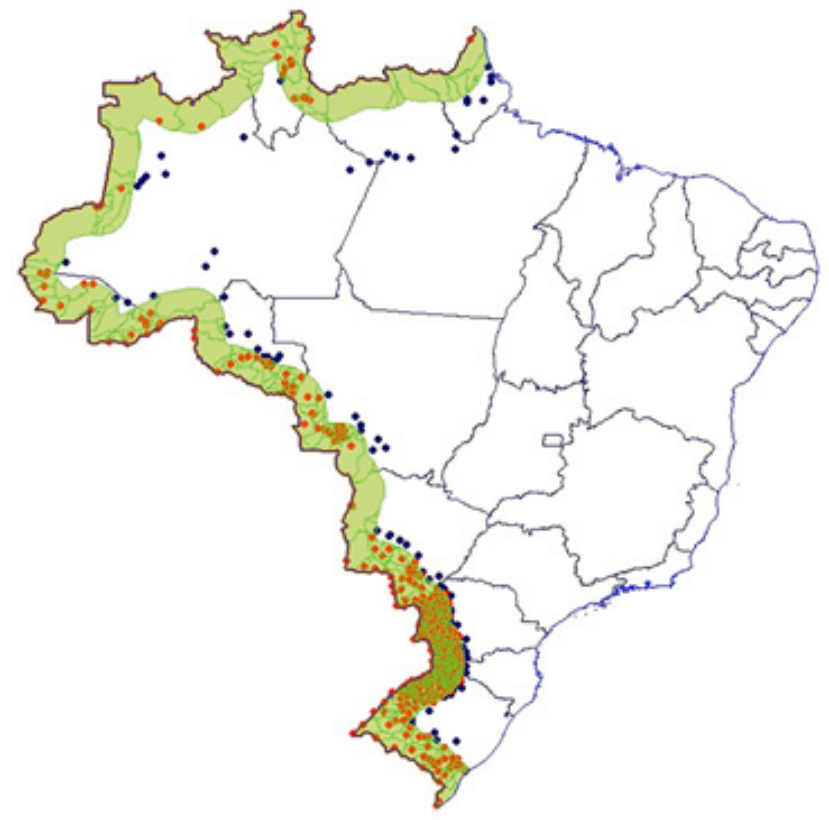

Source: Instituto Brasileiro de Geografia e Estatística (IBGE, 2019). 
In this context, the state of Mato Grosso do Sul deserves to be highlighted. The region has a vast border extension with two countries, Bolivia and Paraguay, including with semiconurbation or conurbation regions; that is why studies of the Mato Grosso do Sul borders become interesting.

In this compass, we should stress the border territorial particularity that the young state of Mato Grosso do Sul has, for many a particularity taken as "illegal activity laboratory" (URQUIZA, 2013 , p. 07). Thus, socio-territorial changes are produced, which generate a geography full of singularity and a scenario that is complex and valuative, from the geopolitical and geoeconomic point of view (OLIVEIRA; PAIXÃO; YONAMINI, 2011).

The Mato Grosso do Sul reality does not escape the crucial logic of globalization: the fluidity of goods, people, and information. Such logic demands, therefore, an infrastructure capable of supporting this intense production and reproduction movement of the capital. In the words of Milton Santos (2012), globalization rests on fixed assets and flows, the fixed assets corresponding to the infrastructure that each location must have to be included in the circuit of financial capitalism, and flows corresponding to the movement of people, goods, and information. Fixed assets and flows should be seen as a whole to enable the already mentioned fluidity through the geographic space.

In this context, amid possible impacts and challenges that emerge, this is a new reality, of enormous demand for infrastructure but, above all, for an intense economic, social, cultural, academic, and legal movement, which span territorial limits of the state of Mato Grosso do Sul, Brazil, reaching countries such as Paraguay, Argentina, and Chile, as demonstrated in Figure 2, and configuring a new development niche, mostly by the evident production of commodities, services, tourism, and new investments that will transit it (SUNAKOZAWA; REYNALDO, 2019).

Figure 2 - Latin-American Route Circuit

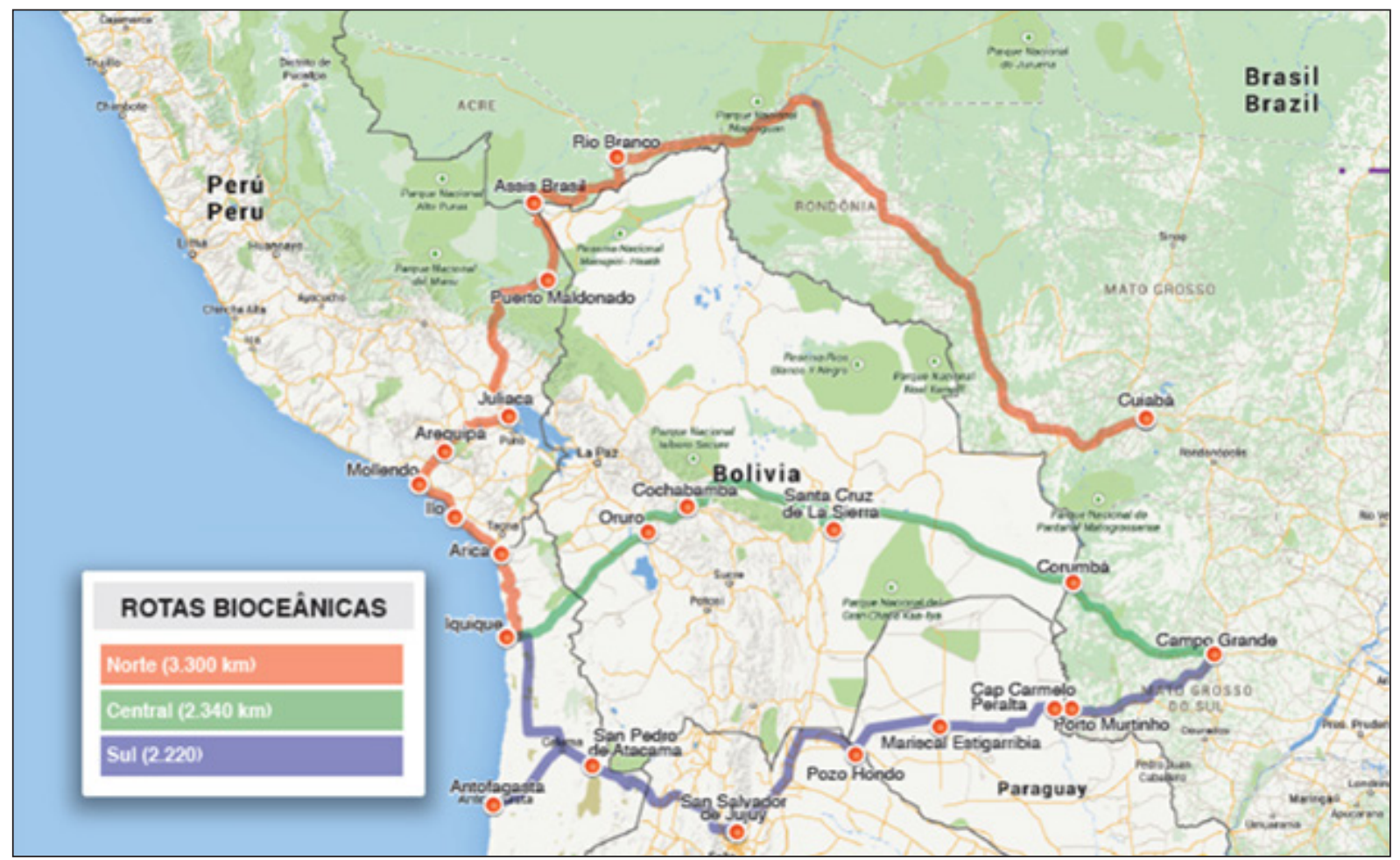

Source: A Crítica (2017). 
Regarding Figure 2, we highlight that the central route has been put on the back burner, the route to the south, in the foreground. The fact is several countries will intensify their commercial, industrial, technological, and academic interchange, bringing a new reality to the countries involved in this circuit. Countries from Mercosul and European Union indicate promising agreements and a break in customs barriers, therefore including the RILA in a social and economic highlight context (SUNAKOZAWA; REYNALDO, 2019).

Thus, the formation of research groups that study and plan actions for implementing public policies strengthening development and regional integration in the RILA context becomes an urgent need. This is a reason why the present study is proposed, which will result in a doctorate thesis that seeks to contribute in this sense.

In such perspective, Amartya Sen reinforces the need to think of development as a right, the right to freedom:

Development requires that the main sources of deprivation of liberty be removed, namely, poverty and tyranny, lack of economic opportunities and systematic destitution, negligence of public services, and intolerance or excessive interference of repressive states. [...] Sometimes the absence of substantive liberty relates directly to economic poverty, which steals from people the liberty of satisfying hunger, of obtaining satisfactory nutrition or medicines for treatable diseases [...]. (SEN, 2000, p. 18).

The idea of development defended by Amartya Sen (2000, p. 18) presupposes the abolition of any and all sources related to the promotion of poverty, along with barriers toward economic development. Yet, it is not easy to break with those development-limiting patterns, given that many countries face obstacles, whether because of historical remnants (the form of colonization, for example) or even bad political management of resources available (natural and human).

In this context, the world thinks of alternative forms of development, to which was given the name of "sustainable development", which aims to promote economic development in a more conscious manner regarding the exploration of natural resources, as well as a more inclusive manner, from the social point of view, seeking to minimize historically constituted social inequalities.

\section{LATIN-AMERICAN INTEGRATION ROUTE (RILA) / BIOCEANIC ROUTE}

The information coming from media content communication and transmission vehicles, such as newspapers and online magazines, has recurrently brought news about the political and economic dispute of two countries of distinct hemispheres, in the West, the United States, and from the East, China. The two gladiators' aim is leadership in world trade, which generates uneasiness and affliction in the globe.

After 20 years of attempts of contracts without agreement between the European Union and Mercosul, the validation speed of treaties between the two economic blocs is now faster, soon leading to their implementation. This act will serve as an instrument for the situations above related, in this way seeking other strategy and trade defense paths, considering the intense and fluid financial movement that unfolds in diverse continents across the globe.

Although seen as a simple, internal, and locational movement by authorities from Brazil and Paraguay, the propaganda of the construction of four bridges in the border area gives rise to a commercial transaction across the globe, as well as opens navigation routes, for example, to 
Pacific ports, specifically Chile's west coast, toward the Asian nations, west portion of the north of South and Central America, Caribbean, United States, and Canada.

Of the connections, above cited, between the border of Brazil and Paraguay, the first of them was engineered for Ponte da Amizade, which interconnects the city of Foz do Iguaçu, in Brazil, with Ciudad del Este, Alto Paraná Department, Paraguay. The second will be located on the Paraná River, in the Marco das Três Fronteiras region, which will connect the city of Foz do Iguaçu, Paraná state, to the city of Presidente Franco, in the Alto Paraná Department, Paraguay. The third bridge, also on the border between the Brazil and Paraguay countries, is being planned for the Paraguay River, to link the city of Porto Murtinho, in Mato Grosso do Sul state, Brazil, to the city of Carmelo Peralta, in the Alto Paraguay Department. The last is supposed to be built over the Apa River, to unite Porto Murtinho, Brazil, and the city of San Lazaro, from the Concepción Department.

It is possible to observe the large dimension of the third linking bridge and the probable legal deductions, from this viability of the bridge construction over the Paraguay River, between Porto Murtinho, Brazil, and Carmelo Peralta, Paraguay. This connection by land supports an appealing/ attractive study observation, about modifications of current civil, cultural, historical, economic, environmental, legal happenings, and migration flows, with the attractive application of transit support with highways, customs, and port, for inputs draining, for example, grains, meat, ore, and other raw materials, at mills or global trades.

These changes occurred in the border areas are intimately connected with the idea of an economic model in which one intends to supply the increasing consumption, especially of agricultural initiatives to feed hundreds of billions of people, in nations of the South, Central, and North America, Asia, and Oceania, going from Brazil, from the Cerrado (Brazilian Savannah), Atlantic Forest, and Pantanal areas, traversing the Paraguayan Chaco zone, north of Argentina, Atacama Desert, Andes Mountains, until arriving at the ports of the north of Chile, Antofagasta, Iquique, and Merijillones. Similarly, one expects high import and access in this large area, of goods coming especially from Asia and the United States, as a consequence of that link.

This area within South America, at first, groups four nations, Brazil, Paraguay, Argentina, and Chile, and has been named Bioceanic Route, because it unites the South-American east coast in the Atlantic Ocean, to the west coast in the Pacific Ocean, or Latin-American Integration Route (RILA), this title of particular interest among businessmen and universities, as the route will unite populations and respective cultures.

\section{DEVELOPMENT AND INTEGRATION OF FEDERAL CONSTITUTIONS IN THE RILA CONTEXT}

The Brazilian Magna Carta, that is to say, the Constitution of the Federative Republic of Brazil, clarifies the intention of the four main pillars for national progress, which it demonstrates in subsection 2 of Article III. The uneasiness about progress and growth in Brazil is current (FOLLONI, 2014), even in the legal field.

The constitutional basis is formed, modestly, from an official letter from 1967, and advances somewhat under the aegis of 1969. However, it is with the young constitution of 1988 that an intense legal agitation and evolution occur. The current norm concedes an in-depth intervention.

In the constitution of 1988, there is a provision about the economic development and social development themes. Yet, we should stress that in several parts of the constitutional text, the 
terms are unified by the term "economic-social development". Therefore, one understands that one type of development cannot invalidate the other (FOLLONI, 2014).

As to international relations in the Brazilian nation, Article IV of the constitutional text should be highlighted:

Art. IV The Federative Republic of Brazil is governed in its international relations by the following principles:

1- national independence;

2- prevalence of human rights;

3- self-determination of peoples;

4- non-intervention;

5- equality between States;

6 - defense of peace;

7- peaceful solution of conflicts;

8- repudiation of terrorism and racism;

9- cooperation between peoples for the progress of humanity;

10- granting of political asylum.

Sole paragraph. The Federative Republic of Brazil will seek the economic, political, social, and cultural integration of peoples from Latin America, aiming at the creation of a LatinAmerican community of nations.

This is what is one concludes in analyzing the 1988 Federal Constitution relative to development, that is, the greatest presupposition is that development unfolds into related themes, for example, the right to education, to the ecologically balanced environment, to research, to decent work, among others (GABARDO, 2009). Therefore, the constitutional text presents itself as an expression of a socializing proposal of a nation that longs for more justice, cooperation, and happiness.

In light of these brief considerations on the development theme in the Federal Constitution of 1988, it becomes vital to have a more attentive look at the constitutions of other Latin American countries, for example, Paraguay, Chile, and Argentina. In this connection, to trace the referred comparison, Legrand points out that:

If the Brazilian comparatist wants to understand a matter of English law, he cannot settle for analyzing it from a positivist point of view. He must also measure it from a cultural view. In the last resort, a positive description (like law, like legal decisions) explains very little or almost nothing. (LEGRAND, 2018, s.p.).

In this sense, the constitution of the Republic of Paraguay, in the context of Article VI announces quality of life as a goal to be reached by the state. To achieve such an aim, the article considers that studying the economic and social development, environment conservation, and the Paraguayan nation's quality of life improvement, is of utmost importance.

Art. 6- QUALITY OF LIFE. [...] The state will also promote research about population factors and their association with economic and social development, environment preservation, and inhabitants' quality of life.

It is curious to observe that, similarly to Brazil's constitution of 1988, the Paraguayan constitution defends the right to an ecologically balanced environment:

The preservation, conservation, recomposition, and improvement of the environment, as well as their reconciliation with integral human development, constitute priority objectives of social interest. These purposes will guide legislation and relevant government policy. (PARAGUAI, 2019). 
It is important to note that the Paraguayan constitution contains some norms of limited efficacy that aim to promote development in areas such as child development (Art. 54), youth's right (Art. 56), right to social development by the access to education (Art. 73), as well as promote the improvement of technical educational (Art. 78) and universities (Art.79).

Regarding education, overall, Paraguay's constitution, in a very similar way to the Brazilian constitution, understands that it must be conducted as a public policy for implementing an idea of development. Like FC/88, the Paraguayan constitution provided the alternative of the state elaborating policies for education, in all spheres of teaching, and having autonomy in higher education (Art. 79).

As regards indigenous protection, a matter of utmost relevance for the countries of America, Paraguay's constitution instituted the community property right for indigenous peoples so that these might develop the most varied forms of life, according to their cultural conceptions, to give continuity to their history and cultural particularities. Of this part of the constitution, one has the idea that the indigenous lands are indivisible, unalienable, indefeasible, and are not subject to taxation or any other type of onerousness. In the body of Article 64, a broad defense of the indigenous peoples' autonomy on Paraguayan soil is noted.

Another essential form of development provided in the Paraguayan constitution consists in the agrarian reform as a fact generating rural development (see articles 114 and 115 content), dismissing the idea of unproductive land (Art. 116). It is interesting to note, moreover, the idea of cooperatives for promoting national economic development, present in the body of Article 113 , and which relates directly to the major theme in this research, development.

Taking into account the several fronts of development, Paraguay's constitution attributed value to national economic development in such a way that it granted the state the competence to implement programs and public policies that conduct global economic activities, and that are, therefore, indicators for the private sector, and imperative in the public sector (Arts. 116 and 117).

Finally, it becomes interesting to observe that, in the body of Article 178, it is provided that all taxation in Paraguay should be directed to fulfilling the nation's interests only. In other terms, one can tell that the creation of taxes lacks support from policies favoring national development, as Article 179 of the constitution prescribes.

Having considered the Paraguayan constitution, we move to a brief analysis of the Argentinian constitution. It is clear right away (particularly in Art. 41) that such a norm desires to preserve the environment to guarantee the human development of future generations. Furthermore, special attention is given as to the preservation of native Argentinian ethnicities (Art. 75).

Concerning indigenous peoples, it is curious to observe that, in the core of Article 75, the Argentinian constitution recognizes the legal personality of ethnicities, a fact not recognized in the above studied constitutions.

Similarly, to the Brazilian and Paraguayan constitutions, Argentine's Magna Carta indicates some values to be followed, namely,

[...] to provide everything relevant to human development, economic progress with social justice, the growth of the national economy, the creation of jobs, the professional training of workers, the defense of the currency value, the scientific and technological research and development, their overall diffusion and beneficial use (Art. 75). 
As seen, limited-efficacy norms were set out, which lend power to public administration for creating and implementing valuable public policies.

No less important, the Chilean constitution should be remembered in the context of this study. In its article 10, education is conceived as the maximum intent of human development. Thus, the state is responsible for stimulating educational development in all spheres, encouraging scientific study and technological development, and in the same way, encouraging the fields of the arts and of the protection of cultures.

Thus, "The constitutions, as organization norms of the States, regulate a set of principles of International Law that serve to guide them in their international relations [...]" (MENEZES, 2007a, p. 213). In a first study, we find an opening that the aforementioned constitutions offer for the economic and social development of the respective nations. However, more than approaching an idea of development, it is necessary and urgent to analyze in more detail the harmonization of norms in the field of RILA, be it by means of government groups and commissions, or even actions of companies and university cooperation.

\section{THE CHALLENGE OF LEGAL HARMONIZATION IN RILA: LEGAL ENVIRONMENT AND LOCAL DEVELOPMENT}

As is well known, the globalization process is not harmonic; in some parts of the world, it happens amid a greater intensity of fixed assets and flows, in others, with less intensity, hence the need for a more detailed analysis to understand each existing economic flow.

Among so many economic flows, there arises the need for guaranteeing legal security in the relationships established between States and companies in this intense financial flow derived from globalization and technology advancement.

The international society, which starts demanding new legal instruments that enable an effective response to the regulation of a globalized and more integrated order, which classic International Law, as was conceived, could no longer afford, comes to alter, substantially, the relationship and way of application of International Law by the States and the legal-normative relationship between International Law and Internal Law. (MENEZES, 2007b, p. 143).

One notes that certain concepts of the Theory of the State come to be reassessed along the process of globalization of the economy. Such a process spans physical frontiers and puts the sovereignty of nation-states at stake (RANIERI, 2013). In this context,

The modern state of the beginning of the 21st century, in its territory and internationally, is faced with a plurality of decision and law-producing centers, not state or suprastate, which implies the relativization of the centrality, unity, and territoriality of state power. Its sovereignty is partaken and shared with the other subjects of the international and regional order, which causes the decay of state authority and loss of the monopoly of political power. On the other hand, the prevalence of economy over politics, which is in large part a result of processes of transnationalization of the supply, production, capital, finance, and consumption markets, and of the state's loss of control over the currency, associated with information technology and society's networked organization relativized the state's sovereignty. (RANIERI, 2013, s.p.).

The fact is that new legal concepts emerge in this scenario, as well as the urgent need for rethinking already existing concepts. Nonetheless, because there is no other state model, the state should be defended as a mediator of social relations, as an order and organization presupposition, the base of current societies. What is more, the state's role in ensuring legal security stands out.

INTERAÇÕES, Campo Grande, MS, v. 22, n. 4, p. 1133-1144, out./dez. 2021. 
[...]. The task, then, is to establish a succinct perspective of the most important devices, which express the constitutional and normative view of the Latin-American states relative to the rules of International Law, in order to seek the engagement of each Latin-American state with the rules of International Law. (MENEZES, 2007a, p. 214).

This is a brief panorama of the legal norms in the context of RILA. There is much to do in terms of legal harmonization (SUNAKOZAWA; REYNALDO, 2019). It is a little-explored field and demands an urgent analysis since the economic and social relations happen instantaneously, where development depends on the economic, social, cultural, and mostly, legal bases in the complex context imposed by globalization.

\section{FINAL CONSIDERATIONS}

Under the aegis of globalization, which values integration, the Latin-American Integration Route (RILA) constitutes a regional economic development center, because of the intense trade of products, services, tourist activities, and investments, from the integration between Brazil, Paraguay, Argentine, and Chile.

Countries of different continents already point to a break in customs tariffs and rise of new economic agreements, bringing closer the countries of RILA and countries of today's greatest and most solid economic bloc, the European Union.

In other words, the RILA is becoming a macro-territory of increasing economic, social, and legal prominence, therefore, thinking the regional development is a priority task, along with drawing up studies and reflections that lead to a possible harmonization and integration of legal norms. These are tasks of the governments, academia, companies, and civil society.

In this context, once the homogenizing discourse of globalization and its socioeconomic consequences occur, aggressively, throughout the globe, the dignity of the human being, the respect to cultural differences, and the access to justice are topics that must not be left aside.

\section{REFERENCES}

ARGENTINA. Constituición da La Nación Argentina. [s.d.]. Available at: https://www.constitution.org/cons/ argentin.htm. Access on: 4 June 2020.

BECKER, B. K. Amazônia: geopolítica na virada do III milênio. Rio de Janeiro: Garamond, 2007.

BRASIL. Constituição da República Federativa do Brasil: texto constitucional promulgado em 5 de outubro de 1988, com as alterações determinadas pelas Emendas Constitucionais de Revisão nos 1 a 6/94, pelas Emendas Constitucionais nos 1/92 a 91/2016 e pelo Decreto Legislativo no 186/2008. [Constituição de 1988]. Brasília, DF: Senado Federal, 2016.

CHILE. Constituición de La República de Chile. [s.d.]. Available at: https://www.camara.cl/camara/media/ docs/constitucion_politica.pdf. Access on: 4 June 2021.

CRíTICA, A. A Rota de Integração Latino-Americana trará novas possibilidades econômicas para o Brasil. A Crítica, Campo Grande, MS, 4 Set. 2017.

FOLLONI, A. A complexidade ideológica, jurídica e política do desenvolvimento sustentável e a necessidade de compreensão interdisciplinar do problema. Revista Mestrado em Direito, Osasco, ano 14, n. 1, p. 6391, 2014. 
FURTADO, R. S. As fronteiras na América Platina: apontamentos sobre a formação da agenda política de integração fronteiriça no âmbito do Mercosur. In: TRINCHERO, Héctor Hugo; OLIVEIRA, Tito Carlos Machado (Org.). Fronteiras Platinas: território e sociedade. Dourados, MS: Editora UFGD, 2012.

GABARDO, E. Interesse público e subsidiariedade. Belo Horizonte: Fórum, 2009.

INSTITUTO BRASILEIRO DE GEOGRAFIA E ESTATÍSTICA. Municípios da faixa de fronteira. IBGE, Rio de Janeiro, 2019. Available at: https://www.ibge.gov.br/. Access on: 4 June 2021.

LEGRAND, P. Como ler o direito estrangeiro. São Paulo: Contracorrente, 2018.

MENEZES, W. A contribuição da América Latina para o Direito Internacional: o princípio da solidariedade. 342 f. 2007. Tese (Pós-Graduação em Integração da América Latina) - Universidade de São Paulo, SãoPaulo, SP, 2007a.

MENEZES, W. O direito internacional contemporâneo e a teoria da transnormatividade. Pensar, Fortaleza, v. 12 , p. 134-144, Mar. 2007b.

OLIVEIRA, T. C. M.; HIGA, T. C. S.; PAIXÃO, R. O.; MOURA, R.; CARDOSO, N. A. Cidades de fronteira e a rede urbana. In: PEREIRA, Rafael Henrique Moraes; FURTADO, Bernardo Alves (Org.). Dinâmica urbanoregional: rede urbana e suas interfaces. Brasília: Ipea, 2011. p. 79-95.

OLIVEIRA, T. C. M.; PAIXÃO, R. O.; YONAMINI, S. S. Mato Grosso do Sul: dinâmica urbano-regional do estado. In: PEREIRA, R. H. M.; FURTADO, B. A. (Org.). Dinâmica urbano-regional: rede urbana e suas interfaces. Brasília: IPEA, 2011.

PARAGUAI. Constituición Nacional de La República Del Paraguay. Asunción, 20 June 1992. Available at: http://jme.gov.py/transito/leyes/1992.html. Access on: 4 June 2021.

RAFFESTIN, C. A ordem e a desordem ou os paradoxos da fronteira. In: OLIVEIRA, T. C. M. (Org.). Território sem limites: estudos sobre fronteiras. Campo Grande: Ed. UFMS, 2005. p. 9-15.

RANIERI, N. B. S. Teoria do Estado: do estado de direito ao estado democrático de direito. Barueri: Manole, 2013.

SANTOS, M. Por uma outra globalização: do pensamento único à consciência universal. 22. ed. Rio de Janeiro: Record, 2012.

SEN, A. Desenvolvimento como liberdade. Tradução de Laura Teixeira Motta. São Paulo: Companhia das Letras, 2000.

SUNAKOZAWA, L. F. J.; REYNALDO, G. O. A Rota de Integração Latino-americana (RILA) diante da globalização: a necessidade urgente da pavimentação jurídica transnacional e territorial. In: FEITOSA, A.; FRANCESCHINI, B.; SILVA, R. B.; BRITO, R. D. (Org.). Perspectivas de direito contemporâneo. Rio de Janeiro: Grupo FGB- Pembroke Collins, 2019. p. 706-21.

URQUIZA, A. H. A. Culturas e histórias dos povos indígenas em Mato Grosso do Sul. Campo Grande, MS: Ed. UFMS, 2013.

\section{About the authors:}

Gabriela Oshiro Reynaldo: Doctorate student and Master's Degree in Local Development from the Dom Bosco Catholic University (UCDB). Graduated in Geography at the State University of Mato Grosso do Sul (UEMS) and Law at UCDB. Teacher of Geography and Current Affairs at schools 
from the private sector in Campo Grande, MS, as well as in prepping courses for military exams, focusing at the ESPCEX exam. Voluntary researcher in extension and researching groups linked to the Route of Latin American Integration (RILA). E-mail: oshiro.gabriela@hotmail.com. Orcid: http://orcid.org/0000-0003-0575-447X.

Lucio Flavio Joichi Sunakozawa: Doctorate in Law at the University of São Paulo (USP). Master's Degree in Local Development at the Dom Bosco Catholic University (UCDB), with focus in the area of Sustainable Development, Collective Environment of Innovation and Disruptive Technologies. Effective member of the Research and Post-Graduation Commission of the Federal Board of the Brazilian Bar Association (OAB). E-mail: professor.lucioflavio@gmail.com. Orcid: https://orcid.org/0000-0002-3656-5279.

Arlinda Cantero Dorsa: Currently attending the postdoctoral internship at the Augusto Motta University Center (UNISUAM), in the Master's Degree and Doctorate Program in Local Development. Doctorate in Portuguese Language at the Pontifical Catholic University of São Paulo (PUC-SP). Master's Degree in Communication and Languages at the Mackenzie Presbyterian University. Graduated in Languages in French at the Dom Aquino Philosophy, Science and Languages College. Graduated in Pedagogy at the Urubupungá Education, Science and Languages College. Full Professor of the Dom Bosco Catholic University (UCDB), in the Law Course. Professor and vice-coordinator of the Post-Graduate Program in Local Development Master's Degree and Doctorate of UCDB. Member of the Historic and Geographic Institute of Mato Grosso do Sul. Leader of the Group of Research in Cultural Heritage, Rights and Diversities, and vice-leader of the Group of Research and Studies in Educational Technology and Distance Learning (GEDEC) of UCDB. Coordinates the project "Bioceanic Route and UniRila (Universities of the Route of Latin American Integration): Learning the existing potentialities as new spaces of development and innovative practices - Continuity", and the project "Migratory governances in Brazil: Contemporary challenges in the 2030 ONU agenda." E-mail: acdorsa@ucdb.br. Orcid: http://orcid.org/0000-0002-1120-0273. 